\title{
P02.129. Individualized chiropractic and integrative care for low back pain: a randomized clinical trial
}

\author{
G Bronfort", M Maiers, R Evans, K Westrom \\ From International Research Congress on Integrative Medicine and Health 2012 \\ Portland, Oregon, USA. 15-18 May 2012
}

\section{Purpose}

To determine the relative effectiveness of multidisciplinary integrative care compared to chiropractic care for chronic LBP in patients over 18 years of age using pain as the primary outcome measure. Secondary outcomes were patient self-reported disability, global perceived effect, general health status, satisfaction, self-efficacy, fear avoidance behavior, lumbar dynamic motion, and trunk muscle strength and endurance.

\section{Methods}

Patients received 12 weeks of care with followup at 6 and 12 months. Both interventions had care teams who followed a care pathway designed to guide evidence based clinical decision making within the intervention groups. Patient profiles, based on a bio-psycho-social perspective, were created based on history, clinical examination findings, and patient preferences. Care teams met weekly to review patient profiles and make treatment recommendations based on patient presentation, the best available evidence, and their clinical experience. Integrative Care included acupuncture, chiropractic care, cognitive behavioral therapy, exercise, massage and medication in different combinations. Chiropractic care included spinal manipulation,selfcare advice, and home exercise.

\section{Results}

Two hundred patients participated. Mixed model longitudinal analysis showed that the integrative care group had statistically significant more pain reduction, perceived global improvement and satisfaction with care in both the short- (up to 12 weeks) and long-term (through 52 weeks; $\mathrm{p} \leq 0.05$ ). The group differences were relatively small.

\section{Conclusion}

Integrative care for chronic low back pain resulted in slightly better short- and long-term outcomes than chiropractic care.

Published: 12 June 2012

doi:10.1186/1472-6882-12-S1-P185

Cite this article as: Bronfort et al:: P02.129. Individualized chiropractic and integrative care for low back pain: a randomized clinical trial. BMC Complementary and Alternative Medicine 2012 12(Suppl 1):P185.

Northwestern Health Sciences University, Bloomington, USA

Submit your next manuscript to BioMed Central and take full advantage of:

- Convenient online submission

- Thorough peer review

- No space constraints or color figure charges

- Immediate publication on acceptance

- Inclusion in PubMed, CAS, Scopus and Google Scholar

- Research which is freely available for redistribution

Northwestern Health Sciences University, Bloomington, USA

ㄷ 2012 Bronfort et al; licensee BioMed Central Ltd. This is an Open Access article distributed under the terms of the Creative Commons 